Virginia Commonwealth University VCU Scholars Compass

2017

\title{
Differential response of barrier island dune grasses to species interactions and burial
}

April Harris

Virginia Commonwealth University, harrisal22@mymail.vcu.edu

Julie C. Zinnert

Virginia Commonwealth University

Donald R. Young

Virginia Commonwealth University

Follow this and additional works at: http://scholarscompass.vcu.edu/biol_pubs

Part of the Biology Commons

(C) Springer Science+Business Media Dordrecht 2017

\section{Downloaded from}

http://scholarscompass.vcu.edu/biol_pubs/40

This Article is brought to you for free and open access by the Dept. of Biology at VCU Scholars Compass. It has been accepted for inclusion in Biology

Publications by an authorized administrator of VCU Scholars Compass. For more information, please contact libcompass@vcu.edu. 


\title{
Differential response of barrier island dune grasses to species interactions and burial
}

\author{
April L. Harris · Julie C. Zinnert • Donald R. Young
}

Received: 5 August 2016/Accepted: 21 February 2017/Published online: 6 March 2017

(C) Springer Science+Business Media Dordrecht 2017

\begin{abstract}
Barrier islands are at the forefront of storms and sea-level rise. High disturbance regimes and sediment mobility make these systems sensitive and dynamic. Island foredunes are protective structures against storm-induced overwash that are integrally tied to dune grasses via biogeomorphic feedbacks. Shifts in dune grass dominance could influence dune morphology and susceptibility to overwash, altering island stability. In a glasshouse study, two dune grasses, Ammophila breviligulata and Uniola paniculata, were planted together and subjected to a $20 \mathrm{~cm}$ burial to quantify morphological and physiological responses. Burial had positive effects on both plants as indicated by increased electron transport rate and total biomass. Ammophila breviligulata performance declined when planted with $U$. paniculata. Uniola paniculata was not affected when planted with A. breviligulata but did have higher water use efficiency and nitrogen use efficiency. Planted in mixture, differential reallocation of biomass occurred between species potentially altering resource acquisition further. As $U$. paniculata migrates into $A$. breviligulata dominated habitat and $A$. breviligulata
\end{abstract}

Communicated by Anna R. Armitage.

A. L. Harris · J. C. Zinnert $(\bowtie) \cdot$ D. R. Young

Department of Biology, Virginia Commonwealth

University, 1000 West Cary St, Richmond, VA 23284,

USA

e-mail: jczinnert@vcu.edu performance diminishes, biotic interactions between these and other species may affect dune formation and community structure. Our study emphasizes the importance of studying biotic interactions alongside naturally occurring abiotic drivers.

Keywords Ammophila breviligulata $\cdot$ Uniola paniculata $\cdot$ Biogeomorphic feedback $\cdot$ Species migration $\cdot$ Climate change

\section{Introduction}

Barrier islands comprise $\sim 15 \%$ of world coastlines (van Heteren 2014; Zinnert et al. 2016). They protect the mainland from storms (Seabloom et al. 2013), protect back-barrier estuaries and wetlands, and provide habitat for rare and endangered plants and animals (Masterson et al. 2014). Barrier islands are sensitive and dynamic systems due to high disturbance frequency, sediment mobility, and biogeomorphic feedbacks (Stallins and Parker 2003; Brantley et al. 2014; Zinnert et al. 2016). Increased frequency in storms have the potential to alter biotic responses of vegetation through abiotic factors such as overwash (Durán and Moore 2013; Miller 2015). Species migrations could further shape dune-building through differentiated responses to overwash.

Within coastal research, biotic feedback and species migrations have largely been ignored in favor 
of physical processes such as storm impacts and sealevel rise. Within terrestrial systems, large bodies of work have dealt with projected or expected species migrations and the effects on ecosystem process (Walther et al. 2002; Parmesan and Hanley 2015). This knowledge is currently lacking for coastal ecosystems. Climate change has the potential to alter coastal systems through increased global temperature (Wang et al. 2014) and increased frequency of storms (Hayden and Hayden 2003). Increased temperature could indirectly alter barrier islands through shifts in flora distribution patterns, while increased storms can result in overwash and sediment burial.

Semitropical plant species may experience a latitudinal expansion due to increased temperatures, which would shift plant community compositions in coastal systems (Gonzalez et al. 2010). On the North American Atlantic coast, specifically the barrier islands of Virginia, the semitropical dune grass Uniola paniculata has the potential to expand its range northward into the habitat of Ammophila breviligulata, the dominant dune grass species of mid-Atlantic coastlines. These two species currently co-occur on the Outer Banks, NC (Hodel and Gonzalez 2013) and sparse populations have been observed on the Virginia barrier islands (Young, personal observation). Expansion into the Virginia barrier islands represents the two species interacting on undeveloped barrier islands unlike the Outer Banks of North Carolina which are heavily managed to control island stability (Dolan 1972).

Rooting strategies of these two dune-building grasses result in different initial dune formations. Foredunes established by A. breviligulata, a $\mathrm{C}_{3}$ or cool season species, are long and continuous along the shoreline (Ehrenfeld 1990; Brantley et al. 2014). Ammophila breviligulata is clonal and has "guerrilla root" morphology (Stallins 2005; Brantley et al. 2014). Connections between ramets are separated by long internodes resulting in widely spaced ramets that influence dune morphology (Ye et al. 2006; Emery and Rudgers 2013; Brantley et al. 2014). It is a dominant pioneer species of foredune habitat that once established, plays an important role capturing sand and creating tall foredunes (Emery and Rudgers 2014). Ammophila breviligulata can withstand very high rates of sand burial, up to $1 \mathrm{~m}$ of sand per year, which significantly contributes to foredune formation (Maun and Lapierre 1984).
In contrast, $U$. paniculata, a $\mathrm{C}_{4}$ or warm season species, displays phalanx rhizome growth. Internode connections between ramets are very short which result in clumps of ramets that create hummocky dunes (Ye et al. 2006). Similar to A. breviligulata, $U$. paniculata is often the dominant species within its range and tolerates burial (Lonard et al. 2011). It is also very tolerant of sea spray (Lonard et al. 2011; Miller et al. 2003). The northern habitat range of $U$. paniculata on the southern barrier islands of Virginia is limited by winter temperatures (Lonard et al. 2011); however, recent climate data show warming during winter months on the Virginia barrier system (Zinnert et al. 2011).

Warmer temperatures associated with climate change could enhance the northern expansion of $U$. paniculata further into the Virginia barrier island system due to its $\mathrm{C}_{4}$ photosynthetic pathway (Lonard et al. 2011). Expansion would most likely occur during an overwash event where waves transport sand across the strand and over the foredune creating an overwash fan (Brantley et al. 2014). Within deposited sand on overwash fans, propagules of $U$. paniculata and $A$. breviligulata could establish alongside one another (Maun 1984; Lonard et al. 2011) resulting in potential for biotic interactions. Although both A. breviligulata and $U$. paniculata are adapted to strandline conditions such as salt spray, sand deposition, and high solar radiation, the difference in photosynthetic pathway $\left(\mathrm{C}_{3}\right.$ vs. $\left.\mathrm{C}_{4}\right)$ could give $U$. paniculata a competitive advantage due to its tolerance for higher temperatures and higher water use efficiency (WUE) when grown with A. breviligulata (Way et al. 2014).

Vegetation change on foredune habitats of barrier islands resulting from range expansion of a species can alter plant responses to burial due to species interactions. Foredune vegetation has a strong impact on dune morphology through influences on sediment deposition and mobility (Stallins and Parker 2003; Hacker et al. 2012; Zarnetske et al. 2012; Miller 2015; Charbonneau et al. 2016). Differences in dune morphology can occur over relatively short time scales (Stallins and Parker 2003) and influence island susceptibility to overwash events (Wolner et al. 2013). This becomes even more important in the future as climate change alters the intensity, frequency, and track of hurricanes (Masselink and Heteren 2014) as well as sea-level rise (Mousavi et al. 2011; Williams 2013). 
Quantifying biotic interactions of dune grasses under abiotic drivers is essential when predicting plant response as both can act together as influencing factors (Zarnetske et al. 2013; He and Bertness 2014). However, there are relatively few studies that examine both biotic interaction and abiotic drivers in an experimental setting. The objective of our study was to determine how growth of the dominant dune grasses A. breviligulata and $U$. paniculata respond when grown in monoculture or mixture planting under burial, a common abiotic driver. Specifically, we quantified physiological and morphological responses of these dune grasses related to growth and productivity. We hypothesized that $U$. paniculata will outperform $A$. breviligulata due to the advantages associated with having a $\mathrm{C}_{4}$ photosynthetic pathway.

\section{Methods}

Experimental design

Ammophila breviligulata (American beachgrass) is a perennial dune grass native to the Atlantic coast with a range from North Carolina, USA to Newfoundland, $\mathrm{CA}$ and shorelines of the five Great Lakes (Emery and Rudgers 2013). Uniola paniculata (sea oats) is perennial, semitropical grass that occurs on dunes in the Bahamas, Cuba, and from eastern Mexico northward to southern Virginia (Hodel and Gonzalez 2013). For our glasshouse study A. breviligulata and U. paniculata ramets ( $\sim 25$ and $30 \mathrm{~cm}$, respectively) were obtained from Cape Coastal Nursery, South Dennis, MA and Coastal Transplants, Bolivia, NC, respectively. Distance between ramet sources was driven by availability constraints. Vegetative propagules of $A$. breviligulata can survive ocean transport for some distance (Maun 1984) resulting in variable source location. Species were planted in three combinations: A. breviligulata alone, $U$. paniculata alone, and in a 50:50 mixture with one another $(n=5$ per combination) (Fig. 1). A total of 6 individual stems were planted per $15 \times 15 \mathrm{~cm}$ pot containing $1.8 \mathrm{~kg}$ of sand. Sand was a 3:1 mixture of unsterilized sand collected from a Virginia barrier island (Hog Island) and commercial sand. The experiment was conducted from late May 2015 to early July 2015 (9 weeks). Glasshouse photosynthetic photon flux density was $\sim 1300 \mu \mathrm{mol} \mathrm{m}{ }^{-1} \mathrm{~s}^{-1}$ with a mean temperature

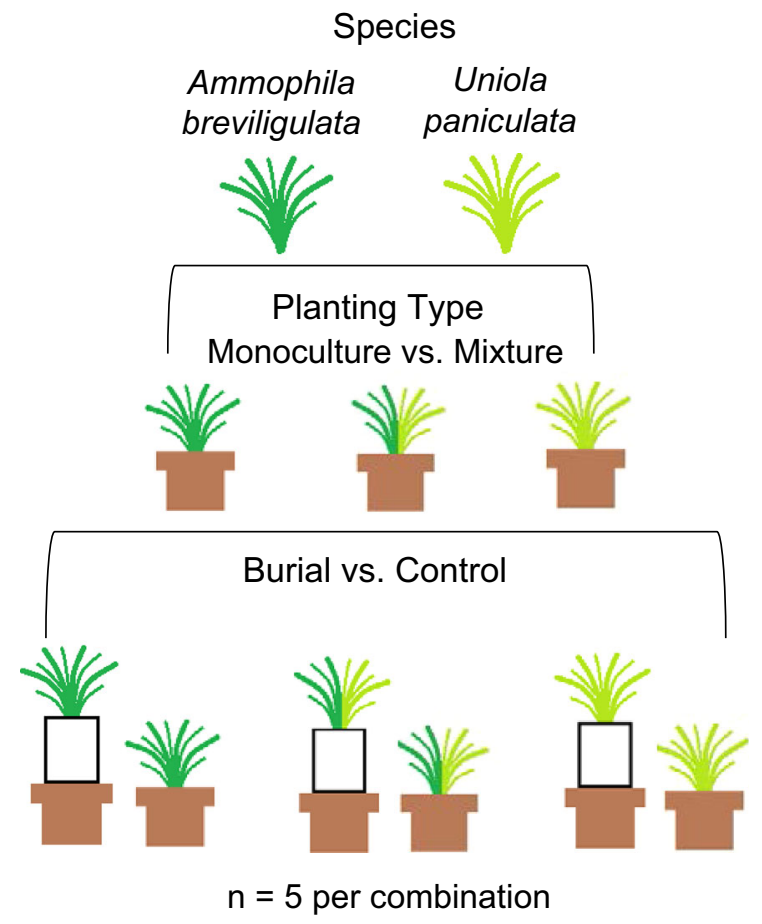

Fig. 1 Multifactorial design consisting of two dune-building grasses, two planting types, and burial treatment $(20 \mathrm{~cm})$ or control $(0 \mathrm{~cm})$

of $31.3{ }^{\circ} \mathrm{C}$ and a mean daily high of $40{ }^{\circ} \mathrm{C}$ (Thermodata ibutton data logger). Glasshouse temperatures are characteristic of those on Hog Island, VA, during the summer (Thompson et al. 2017).

A $1 \mathrm{~cm}$ sand addition was given to all plants at the beginning of the experiment to promote vigor and stimulate growth, and all plants were trimmed to $35 \mathrm{~cm}$ to standardize height. For burial treatment, one half of each planting type received an additional $20 \mathrm{~cm}$ burial to simulate overwash (Fig. 1). A $20 \mathrm{~cm}$ burial was chosen because this represents possible sand deposition from a single storm event on the Virginia barrier islands (Harris, personal observation). Reference plants did not receive additional burial.

To limit nutrient stress, each pot was treated with $25 \mathrm{ml}$ of Hoagland's solution (Hoagland and Arnon 1950) diluted to $50 \mathrm{ml}$ with tap water, twice during the study. Plants were kept well watered throughout the experiment. Instant Ocean by Aquarium Systems, mixed to a diluted concentration of sea water $(20 \mathrm{ppt})$, was sprayed on all plants once weekly to simulate sea spray. Sea spray solution was rinsed off leaves through 
watering $24 \mathrm{~h}$ later to ensure leaf necrosis did not occur.

\section{Measurements}

Physiological measurements were conducted at the end of the experiment on one leaf from each species in each pot. Measurements were taken at midday (1100-1300 h) on cloudless days. Stomatal conductance to water vapor diffusion $\left(\mathrm{g}_{\mathrm{s}} \mathrm{mmol} \mathrm{H}_{2} \mathrm{O} \mathrm{m} \mathrm{m}^{-2}\right.$ $\mathrm{s}^{-1}$ ) was quantified using a porometer (SC-1 Leaf Porometer, Decagon Devices Inc., USA). Electron Transport Rate (ETR), a measure of photosynthetic potential, was measured using the miniPAM (Walz, Germany).

At the end of the experiment, plant height was measured with a meter stick from the pre-burial sand surface to the tip of the longest leaf. Relative growth rate (RGR) was calculated from height measurements using the following equation: $R G R=\left(\ln \cdot L_{2}-\ln \cdot L_{1}\right) /$ $\left(\mathrm{t}_{2}-\mathrm{t}_{1}\right)$ where $\mathrm{L}_{1}$ and $\mathrm{L}_{2}$ are starting height and final height and $t_{1}$ and $t_{2}$ are start and end of experiment in days. Number of alive leaves were counted. Aboveground and belowground biomass were separated, oven dried at $60{ }^{\circ} \mathrm{C}$ for $72 \mathrm{~h}$, and weighed on a digital scale. Change in contribution (CC) is the amount of biomass, a species attained in a mixture divided by the expected amount from monoculture plantings minus one (Williams and McCarthy 2001). This gives the proportional change in contribution of biomass in mixture versus monoculture plantings, allowing a comparison of species in different planting combinations (Williams and McCarthy 2001). CC was calculated from biomass weight using the following set of equations:

$\mathrm{CC}_{\mathrm{A}}^{\mathrm{D}}=\left(Y_{\mathrm{AB}}^{\mathrm{D}} /\left(Y_{\mathrm{AB}}^{\mathrm{D}}+Y_{\mathrm{BA}}^{\mathrm{D}}\right)\right) /\left(\left(p_{\mathrm{A}} Y_{\mathrm{A}}^{\mathrm{D}}\right) /\left(p_{\mathrm{A}} Y_{\mathrm{A}}^{\mathrm{D}}+p_{\mathrm{B}} Y_{\mathrm{B}}^{\mathrm{D}}\right)\right)-1$

$\mathrm{CC}_{\mathrm{B}}^{\mathrm{D}}=\left(Y_{\mathrm{BA}}^{\mathrm{D}} /\left(Y_{\mathrm{AB}}^{\mathrm{D}}+Y_{\mathrm{BA}}^{\mathrm{D}}\right)\right) /\left(\left(p_{\mathrm{B}} Y_{\mathrm{B}}^{\mathrm{D}}\right) /\left(p_{\mathrm{A}} Y_{\mathrm{A}}^{\mathrm{D}}+p_{\mathrm{B}} Y_{\mathrm{B}}^{\mathrm{D}}\right)\right)-1$

obtained from Williams and McCarthy (2001), where $\mathrm{CC}_{\mathrm{A}}^{\mathrm{D}}$ is the change in contribution of species $\mathrm{A}$ at density $\mathrm{D}, \mathrm{CC}_{\mathrm{B}}^{\mathrm{D}}$ is the change in contribution of species $\mathrm{B}$ at density $\mathrm{D}, Y_{\mathrm{AB}}^{\mathrm{D}}$ is the yield of species $\mathrm{A}$ in the presence of species $\mathrm{B}$ at density $\mathrm{D}, Y_{\mathrm{BA}}^{\mathrm{D}}$ is the yield of species $\mathrm{B}$ in the presence of species A at density $\mathrm{D}, Y_{\mathrm{A}}^{\mathrm{D}}$ is the yield of species $\mathrm{A}$ in monoculture at density $\mathrm{D}$, $Y_{\mathrm{B}}^{\mathrm{D}}$ is the yield of species B in monoculture at density
$\mathrm{D}$, and $p_{\mathrm{A}}$ is the proportion with which species A was sown, and $p_{B}$ is the proportion with which species $B$ was sown such that $p_{\mathrm{A}}+p_{\mathrm{B}}=1$ is always true (Williams and McCarthy 2001). CC $>1.0$ indicates that a species grew better in an interspecific mixture than in monoculture. In contrast, $\mathrm{CC}<1.0$ indicates that species grew better in monoculture than with another species. Increases or decreases in CC indicate the percent increase or decrease in biomass (Williams and McCarthy 2001).

$\delta^{13} \mathrm{C}, \% \mathrm{~N}, \% \mathrm{C}, \mathrm{C}: \mathrm{N}$ measurements were obtained from each plant to provide insight into nutrient and water use efficiency. Plant leaves were dried at $60{ }^{\circ} \mathrm{C}$ for $72 \mathrm{~h}$ and ground into a fine powder with a handheld electric grinder. Further processing (i.e., weighing and encapsulating), nutrient, and isotope analysis were conducted at the Cornell University Stable Isotope Lab, Ithaca, New York, USA.

\section{Statistical analysis}

Three-factor analysis of variance (ANOVA) quantified variations in measurement variables due to burial, species, and planting scheme (monoculture vs. mixture). For significant three-way interactions, twofactor analysis of variance was used to further examine planting type $\mathrm{x}$ burial interactions within each species. Two-factor analysis of variance was also used to quantify variations in burial and species for change in contribution. Drawing broad conclusions from multiple individual measures that are correlated with one another, e.g., plant morphological and physiological traits, can be difficult. Multivariate analysis aids in the interpretation of multiple correlated measures by expressing them in fewer dimensions through data reduction. Principal components analysis (PCA, PCORD software v. 5.10) of all measurement variables were used to separate species and treatments and determine which traits were most important for influencing separation. Measurement variables were standardized using a correlation matrix. Axes were retained if observed eigenvalues exceeded brokenstick eigenvalues (Jackson, 1993). Resulting PCA groups were compared using multiple response permutation procedures (MRPP) with the same measurement variables as in the PCA. Measurement variables were standardized using Z-scores. 
Table 1 Three-way ANOVA results (f,p) of electron transport rate (ETR), stomatal conductance $\left(\mathrm{g}_{\mathrm{s}}\right), \delta^{13} \mathrm{C}, \% \mathrm{~N}, \% \mathrm{C}, \mathrm{C}: \mathrm{N}$, total biomass, relative growth rate (RGR), and number of alive leaves for the independent variables species (S), planting (P), and Burial (B)

\begin{tabular}{lccccccc}
\hline & $\mathrm{S}$ & $\mathrm{P}$ & $\mathrm{B}$ & $\mathrm{S} \times \mathrm{P}$ & $\mathrm{S} \times \mathrm{B}$ & $\mathrm{P} \times \mathrm{B}$ & $\mathrm{S} \times \mathrm{P} \times \mathrm{B}$ \\
\hline ETR & $7.9, \mathbf{0 . 0 0 8}$ & $1.9,0.174$ & $19.1, \mathbf{0 . 0 0 0 1}$ & $2.3,0.140$ & $0.6,0.437$ & $1.3,0.266$ & $0.2,0.631$ \\
$\mathrm{~g}_{\mathrm{s}}$ & $1.7,0.206$ & $5.2, \mathbf{0 . 0 2 9}$ & $2.2,0.145$ & $8.2, \mathbf{0 . 0 0 7}$ & $1.2,0.277$ & $0.2,0.625$ & $0.2,0.623$ \\
$\delta^{13} \mathrm{C}$ & $7587.5,<\mathbf{0 . 0 0 0 1}$ & $1.1,0.310$ & $1.3,0.257$ & $10.7, \mathbf{0 . 0 0 2 5}$ & $0.2,0.651$ & $1.5,0.224$ & $2.2,0.145$ \\
\% N & $39.8,<\mathbf{0 . 0 0 0 1}$ & $1.0,0.318$ & $9.2, \mathbf{0 . 0 0 0 1}$ & $18.2, \mathbf{0 . 0 0 0 1}$ & $0.8,0.387$ & $0.2,0.632$ & $0.8,0.372$ \\
\% C & $0.1,0.775$ & $1.4,0.248$ & $4.1,0.051$ & $2.3,0.136$ & $0.4,0.514$ & $3.2,0.082$ & $0.2,0.700$ \\
C:N & $38.0,<\mathbf{0 . 0 0 0 1}$ & $7.2, \mathbf{0 . 0 1 1}$ & $11.4, \mathbf{0 . 0 0 2}$ & $24.9,<\mathbf{0 . 0 0 0 1}$ & $3.3,0.078$ & $2.5,0.123$ & $3.8,0.061$ \\
Total biomass & $4.4, \mathbf{0 . 0 4 4}$ & $17.7, \mathbf{0 . 0 0 0 2}$ & $4.2, \mathbf{0 . 0 4 8}$ & $8.7, \mathbf{0 . 0 0 6}$ & $0.4,0.537$ & $0.1,0.789$ & $0.3,0.569$ \\
AGB & $3.4,0.075$ & $0.6,0.434$ & $0.8,0.379$ & $0.2,0.688$ & $7.3, \mathbf{0 . 0 1 1}$ & $2.6,0.119$ & $5.9, \mathbf{0 . 0 2 1}$ \\
BGB & $16.5, \mathbf{0 . 0 0 0 3}$ & $36.3,<\mathbf{0 . 0 0 0 1}$ & $0.8,0.392$ & $7.6, \mathbf{0 . 0 0 9}$ & $1.0,0.323$ & $0.1,0.801$ & $0.6,0.460$ \\
RGR & $227.8,<\mathbf{0 . 0 0 0 1}$ & $5.4, \mathbf{0 . 0 2 7}$ & $26.4,<\mathbf{0 . 0 0 0 1}$ & $11.2, \mathbf{0 . 0 0 2}$ & $8.4, \mathbf{0 . 0 0 7}$ & $0.3,0.568$ & $6.4, \mathbf{0 . 0 1 6}$ \\
\# of Alive leaves & $52.9,<\mathbf{0 . 0 0 0 1}$ & $1.8,0.183$ & $0.1,0.766$ & $25.0,<\mathbf{0 . 0 0 0 1}$ & $17.5, \mathbf{0 . 0 0 0 2}$ & $8.1, \mathbf{0 . 0 0 8}$ & $2.7,0.111$ \\
\hline
\end{tabular}

Bold indicates significance at $\alpha=0.05$. Degrees of freedom are 7, 34 for all measures

\section{Results}

Physiology

There were no significant species $\mathrm{x}$ planting type $\mathrm{x}$ burial interactions for physiological measurements (ETR, $\mathrm{g}_{\mathrm{s}}, \delta^{13} \mathrm{C}, \% \mathrm{~N}, \mathrm{C}: \mathrm{N}$ ) (Table 1). There were no interactions for electron transport rate (ETR) but there was an effect of species and burial; ETR was enhanced for both species with burial. Uniola paniculata had a higher mean ETR than A. breviligulata under both burial regimes (Fig. 2). While not significant, there was a trend of $A$. breviligulata monoculture planting mean ETR being higher when compared to being grown in mixture with $U$. paniculata (Fig. 2).

All other physiological measurements $\left(\mathrm{g}_{\mathrm{s}}, \delta^{13} \mathrm{C}\right.$, $\% \mathrm{~N}, \mathrm{C}: \mathrm{N})$ had a significant species $\mathrm{x}$ planting type interaction (Table 1). Stomatal conductance was significant among planting type (Table 1). When planted with A. breviligulata, U. paniculata stomatal conductance experienced a $34.8 \%$ increase with burial compared to control, whereas buried monoculture plantings only increased $18.4 \%$. Stomatal conductance of A. breviligulata grown in monoculture was higher than mixture plantings (Table 2). $\delta^{13} \mathrm{C}$ was higher for $U$. paniculata than A. breviligulata (Table 1). Percent nitrogen was higher for $A$. breviligulata than $U$. paniculata and burial was higher than controls (Table 1; Fig. 2). Percent nitrogen had a significant species x planting type interaction where A. breviligulata had higher percent nitrogen in monoculture relative to mixture plantings and $U$. paniculata showed the opposite response with higher nitrogen in mixture plantings than monoculture (Fig. 2). C:N was higher for $U$. paniculata than A. breviligulata and buried plants had an $18.1 \%$ lower $\mathrm{C}: \mathrm{N}$ than controls (Tables 1, 2).

\section{Morphology}

Total biomass had a significant species x planting type interaction (Table 1). Total biomass for monoculture plantings for both species was higher than for mixture plantings and burial yielded higher biomass than controls (Table 1). Ammophila breviligulata total biomass was higher than U. paniculata (Table 1). Change in contribution for aboveground biomass (CCAB) had a significant species $\mathrm{x}$ planting type interaction $\left(\mathrm{F}_{3,16}=11.2, p=0.004\right)$ where A. breviligulata decreased in aboveground biomass when not buried but and increased when buried in relation to monoculture plantings (Fig. 3). Uniola paniculata showed the opposite response where aboveground biomass increased when not buried but decreased when buried (Fig. 3). Change in contribution for belowground biomass (CCBB) had a significant effect of species $\left(\mathrm{F}_{3,16}=4.4, p=0.009\right)$ where A. breviligulata belowground biomass decreased and $U$. 


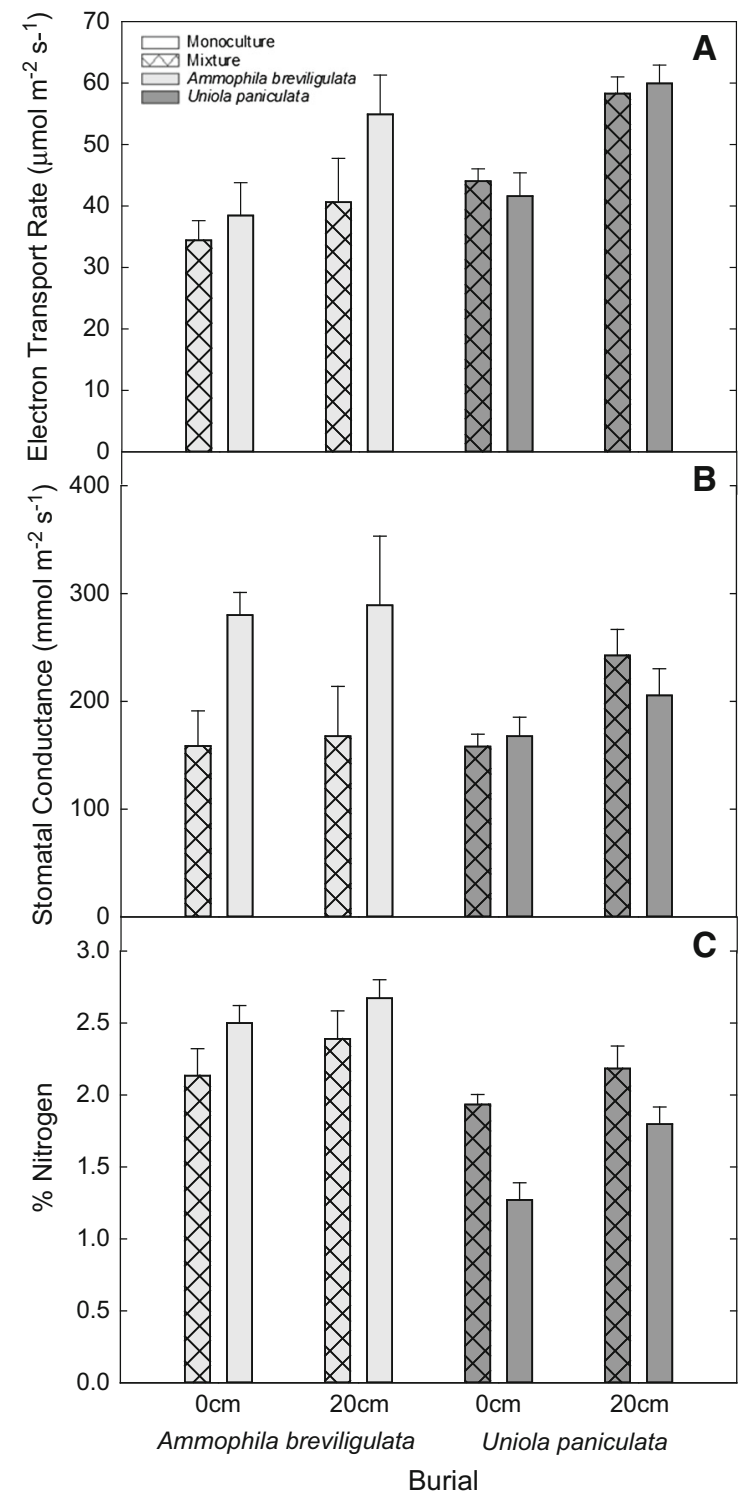

Fig. 2 Ammophila breviligulata and Uniola paniculata electron transport rate, stomatal conductance, and \% nitrogen for control/buried treatment and monoculture/mixture planting type. Values are means \pm 1 standard error

paniculata increased when compared to respective monoculture plantings (Fig. 3).

Relative growth rate (RGR) exhibited significant species $\times$ planting type $\times$ burial interaction (Table 1 ). Ammophila breviligulata monoculture planting RGR was higher than mixture planting; however, burial had no effect (Table 2). Uniola paniculata displayed an opposite pattern where RGR was higher for buried treatment but planting type had no effect (Table 2).
Number of alive leaves exhibited a significant species $\times$ planting type interaction (Table 1). Uniola paniculata mixture planting had more leaves than monoculture planting and A. breviligulata monoculture planting had more leaves than mixture plantings (Table 2). It also exhibited a significant species $\times$ burial interaction, where burial increased leaf number of $U$. paniculata (Table 2), and planting type $\times$ burial interaction (Table 1). Uniola paniculata was higher than $A$. breviligulata with the exception of $A$. breviligulata control monoculture (Table 2).

Combined traits

Principal components analysis axis 1 explained $32.8 \%$ of the variation with $\delta^{13} \mathrm{C}(r=-0.94)$ and RGR $(-0.81)$ being most influential in providing separation (Table 3). Axis 2 explained $28.5 \%$ of data variation. Total biomass $(r=0.83)$ and ETR $(r=0.68)$ were most influential in providing separation (Table 3 ). The four resulting groups (A. breviligulata monoculture vs. mixture, U. paniculata buried vs. control) from PCA were significantly different (MRPP, $t=-16.89$, $A=0.47, p<0.0001$; Fig. 4). Uniola paniculata separated completely from A. breviligulata. Ammophila breviligulata grouping further divided into monoculture plantings versus mixture plantings, while U. paniculata separated based on burial level (Fig. 4).

\section{Discussion}

Coastal drivers, such as storms and sea-level rise, that alter sediment movement have gained attention because of their ability to restructure coastlines (Roelvink et al. 2009). Biotic interactions also play an important role in the structure and function of barrier islands (Stallins 2005; Feagin et al. 2015). As climate change alters abiotic conditions and range expansion of species occurs, it is crucial to understand biotic interactions with present species. Uniola paniculata has the potential to expand northward along the Atlantic coast into A. breviligulata dominated habitat. This has been documented on the Virginia barrier islands (Young, personal observation). The relationship between A. breviligulata and U. paniculata, and response both morphologically and physiologically, to environmental factors such as burial may have ecosystem consequence based on root growth strategy 


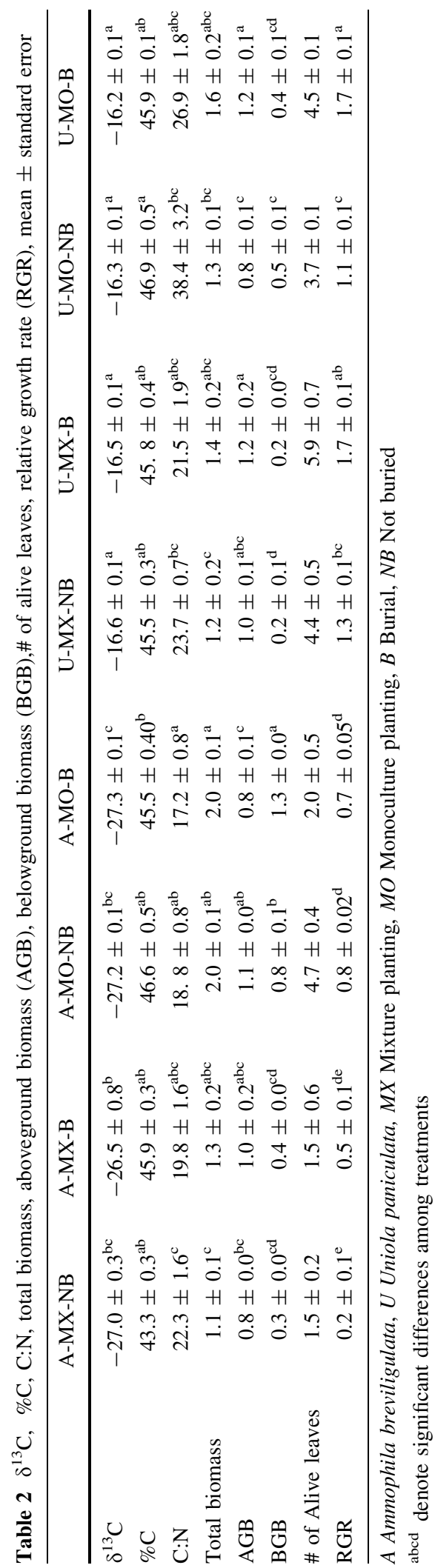

(Stallins and Parker 2003; Charbonneau et al. 2016). Understanding potential biotic interactions between these two dune grasses and response to burial is the first step in predicting future dune communities which may affect dune morphology under climate change scenarios (Stallins and Parker 2003). Our study demonstrates that $A$. breviligulata and $U$. paniculata, species adapted to withstand foredune environmental conditions, differentially respond when planted in a mixture vs. monoculture and when buried.

Uniola paniculata exhibited more robust physiology relative to A. breviligulata as evidenced in higher electron transport rate (ETR). This was expected given the $\mathrm{C}_{4}$ photosynthetic pathway of $U$. paniculata (Taylor et al. 2010). Burial had a positive effect on both species through higher ETR and total biomass relative to controls. Our results of higher A. breviligulata ETR agree with previous findings of positive response to burial (Disraeli 1984; Maun and Lapierre 1984; Yaun et al.1993). Uniola paniculata physiological response to burial is less documented (Wagner 1964). We report U. paniculata having higher ETR and relative growth rate (RGR) when buried. Positive responses are needed as survival mechanisms in foredune environments in order to recover from frequent burial by overwash events.

Relative to monoculture plantings, our results indicate A. breviligulata physiological and morphological performance declined when planted with $U$. paniculata. Conversely, U. paniculata did not appear to be affected when planted with A. breviligulata. This can be seen at a physiological level which predicates whole plant responses to stressors. ETR and relative growth rate (RGR) for $A$. breviligulata mixture plantings were reduced and directly contributed to lower total biomass seen in the change in contribution. This demonstrates that $A$. breviligulata vigor is reduced in the presence of $U$. paniculata. Uniola paniculata ETR and RGR did not decrease vigor when planted with A. breviligulata.

Change in contribution showed that when grown together, total biomass was reduced for A. breviligulata and stimulated for $U$. paniculata relative to monoculture plantings, and resources were reallocated under control and burial conditions. Under control conditions, A. breviligulata aboveground biomass was reduced relative to monoculture and $U$. paniculata aboveground biomass increased. Burial stimulated $A$. breviligulata allocation of resources aboveground in 


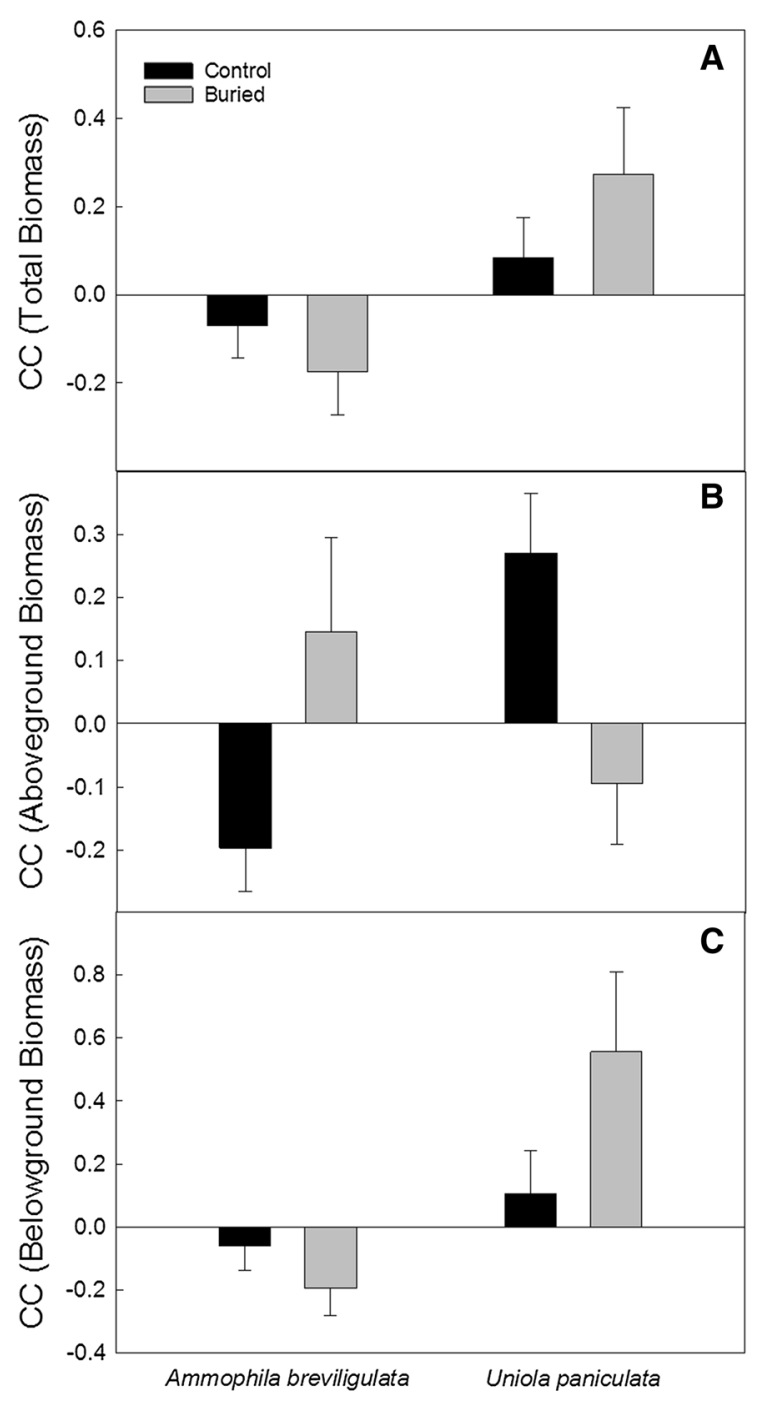

Fig. 3 Ammophila breviligulata and Uniola paniculata mixture paintings change in contribution for total (a), aboveground (b), and belowground biomass (c) when compared to monoculture plantings. Values are means \pm 1 standard error

the presence of $U$. paniculata. In the presence of $A$. breviligulata, burial positively affected $U$. paniculata belowground biomass. Reallocation of resources into aboveground traits allows for quick response to sand deposition and is important in dune-building. However, the overall reduction in total biomass and resulting reallocation can affect the mechanisms by which these dune grasses utilize fresh water and nutrients. This is important due to limited availability of both within the strand environment (Frosini et al. 2012). High water use efficiency (WUE; carbon gain
Table 3 Pearson correlation of measurement variables with principal component axes 1 and 2

\begin{tabular}{lrr}
\hline Variables & PCA 1 & PCA 2 \\
\hline ETR & -0.33 & 0.68 \\
$\mathrm{~g}_{\mathrm{s}}$ & 0.27 & 0.61 \\
$\delta^{13} \mathrm{C}$ & -0.94 & -0.01 \\
$\% \mathrm{~N}$ & 0.74 & 0.41 \\
$\% \mathrm{C}$ & -0.07 & -0.02 \\
$\mathrm{C}: \mathrm{N}$ & -0.66 & -0.42 \\
AGB & -0.36 & 0.67 \\
BGB & 0.54 & 0.52 \\
Total biomass & 0.21 & 0.83 \\
RGR & -0.81 & 0.46 \\
\# Alive leaves & -0.65 & 0.58 \\
\hline
\end{tabular}

per water use) is important due to low water holding capacity of sandy soils (Uzoma et al. 2011). High nitrogen use efficiency (NUE; carbon gain per nitrogen use) is essential in the strand environment due to lack of nutrients in sandy soils (Dilustro and Day 1997).

WUE can be determined through $\delta^{13} \mathrm{C}$ due to the ability of carbon isotopes to integrate eco-physiological measures associated with gas exchange through time (Esquivias et al. 2015). Uniola paniculata was more water and nitrogen efficient than A. breviligulata, based on $U$. paniculata having higher $\delta^{13} \mathrm{C}$ and carbon to nitrogen ratio compared to A. breviligulata. This was expected due to stomatal regulation and less ribulose-1,5-bisphosphate carboxylase/oxygenase (RUBISCO; which reduces nitrogen content) in $U$. paniculata, a $\mathrm{C}_{4}$ plant (Taylor et al. 2010). These traits allowed $U$. paniculata to sustain a greater number of living leaves than A. breviligulata. Ammophila breviligulata monoculture planting sustained the highest number of leaves, whereas $U$. paniculata sustained the highest number of leaves when planted in mixture with A. breviligulata. The number of living leaves combined with the allocation of biomass seen in change in contribution could allow for greater success of $U$. paniculata within the foredune system as it migrates northward along the Atlantic seaboard into A. breviligulata dominated habitat.

When all measures were integrated together, it was clear that A. breviligulata was most affected by planting type. Uniola paniculata responded inversely, with burial contributing more to grouping than 


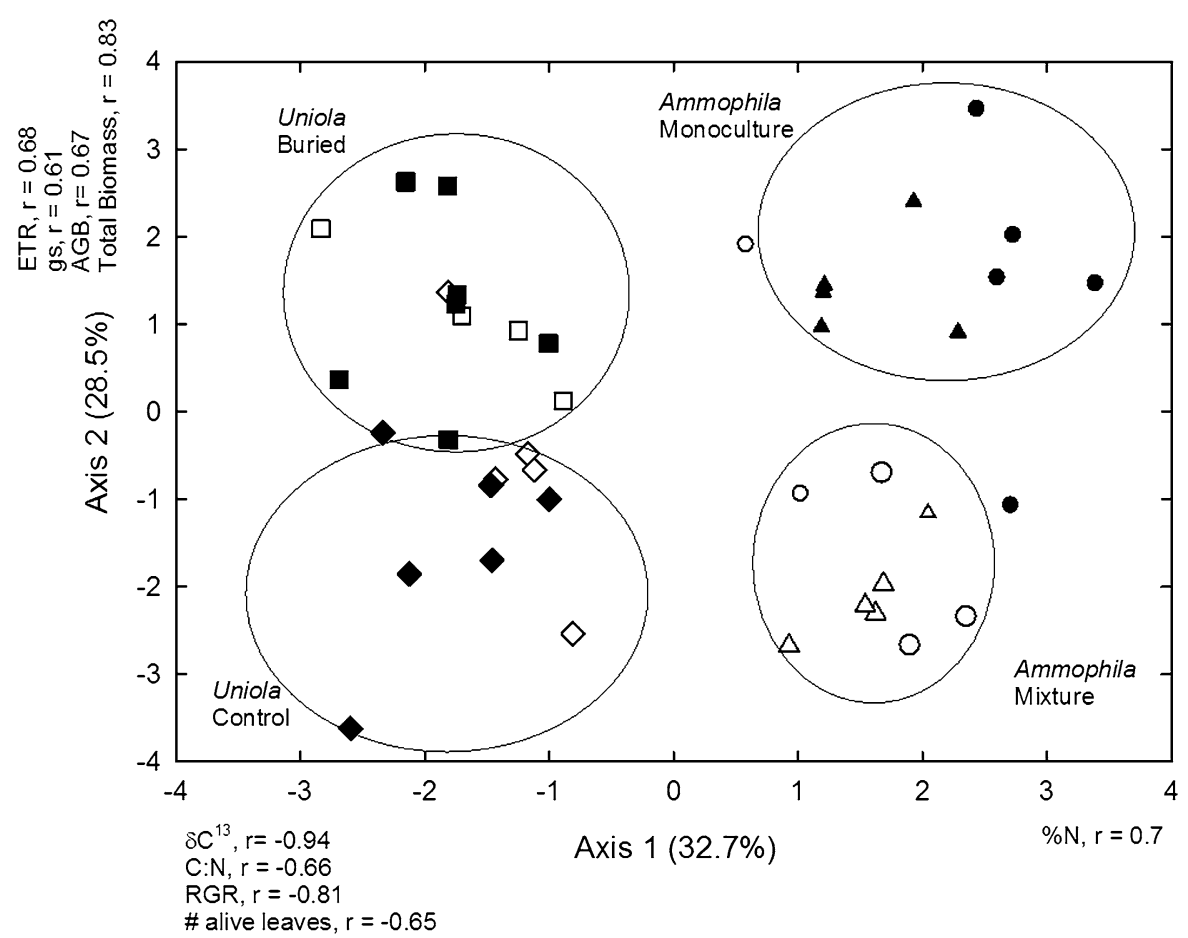

Fig. 4 Principal Component Analysis (PCA) ordination for species, planting type, and burial. PCA axis 1 and 2 are shown. Circles are buried Ammophila breviligulata, triangles are control A. breviligulata, squares are buried Uniola paniculata,

planting type. These alterations in responses indicate that $A$. breviligulata has a diminished performance capacity in the presence of $U$. paniculata. Stallins (2002) observed at the Core Banks of North Carolina, USA, that $U$. paniculata had greater absolute species cover (17\%) than A. breviligulata (1\%). Only one site out of five had a greater $A$. breviligulata absolute species cover than $U$. paniculata (Stallins 2002). At the other four sites, $U$. paniculata had a higher absolute species cover (Stallins 2002). Our results, which suggest that $A$. breviligulata performance diminishes when planted with $U$. paniculata, correspond with these field species cover observations because in areas of high $U$. paniculata cover, $A$. breviligulata cover is reduced. Although we used a northern population of A. breviligulata in our glasshouse study, these corresponding observations from plants growing together in the field indicate that plant source may not be a contributing factor in the results presented.

Potential island impacts due to climate change shifts in dominant dune grass species and the results of and diamonds are control U. paniculata. Open symbols indicate mixture planting, and solid symbols indicate monoculture planting. Four significantly different groups were observed

this study documenting $A$. breviligulata and $U$. paniculata interactions, underscores the importance of understanding dune grass biotic interactions (Zarnetske et al. 2013). These ecosystem engineers are at the forefront of barrier island change as foredune morphology has the ability to influence disturbance regimes through susceptibility to overwash (Wolner et al. 2013; Brantley et al. 2014). Migrating species interaction with local host communities has to be examined alongside co-occurring environmental drivers, as species interactions could shift with altered abiotic conditions (Zarnetske et al. 2013; He and Bertness 2014). Plant communities on barrier island systems, which cope with multiple abiotic drivers simultaneously such as sea spray, burial, high radiation, salt water intrusion, and limited access to nutrients, demonstrate the need for species interactions and environmental drivers to be studied together. It is through differential dune grass interactions that feedbacks with foredune morphology could be altered, shifting the future of barrier island stability and community composition. 


\section{Conclusion}

Barrier island systems are important to study because they are at the forefront of storms and sea-level rise, and provide valuable services. To understand how barrier island dune grasses will respond in the future, it is essential to study the biogeomorphic relationship between dune species in response to sediment manipulation. As dune grass species shift due to climate change, the role of biotic interactions in response to abiotic drivers such as burial must be understood. Our study is unique because it examined both species interactions and burial jointly, while measuring both plant morphological and physiological responses. The most noteworthy result of this study is that $A$. breviligulata performance decreased in the presence of $U$. paniculata. This response has implications for coastal dune morphology due to species differences in rooting strategy and dune-building. Overall, this demonstrates the importance of studying species interactions along with environmental drivers, as this could shift individual species response.

Acknowledgements This work is supported in part by the National Science Foundation grant EAR-1324973. The authors thank Steve Mercer of Coastal Transplants for plants, Joe Brown, Audrey Kirschner, Joey Thompson, Abby Nelson, Elsemarie deVries and Gary Long for help with planting and measurements.

\section{References}

Brantley ST, Bissett SN, Young DR, Wolner CWV, Moore LJ (2014) Barrier island morphology and sediment characteristics affect the recovery of dune building grasses following storm-induced overwash. PLoS ONE 9:e104747

Charbonneau BR, Wnek JP, Langley JA, Lee G, Balsamo RA (2016) Aboveground vs. belowground plant biomass along a barrier island: implications for dune stabilization. J Environ Manage 182:126-133

Dilustro JJ, Day FP (1997) Aboveground biomass and net primary production along a Virginia barrier island chronosequence. Am Midl Nat 137:27-38

Disraeli DJ (1984) The effect of sand deposits on the growth and morphology of Ammophila breviligulata. J Ecol 72:145-154

Dolan R (1972) Barrier dune system along the Outer Banks of North Carolina: a reappraisal. Science 176:286-288

Durán O, Moore LJ (2013) Vegetation controls on the maximum size of coastal dunes. Proc Natl Acad Sci 110: $17217-17222$

Ehrenfeld JG (1990) Dynamics and processes of barrier island vegetation. Aquat Sci 2:437-480
Emery SM, Rudgers JA (2013) The impact of simulated climate change and fungal symbionts on survival and growth of a foundation species in sand dunes. Oecologia 173: 1601-1612

Emery SM, Rudgers JA (2014) Biotic and abiotic predictors of ecosystem engineering traits of the dune building grass Ammophila breviligulata. Ecosphere 5:87

Esquivias MP, Zunzunequi M, Barradas MCD, Alvarez-Cansino L (2015) Competitive effect of a native-invasive species on a threatened shrub in a Mediterranean dune system. Physiol Ecol 177:133-146

Feagin RA, Figlus J, Zinnert JC, Sigren J, Martinez ML, Silva R, Smith WK, Cox D, Young DR, Carter G (2015) Going with the flow or against the grain? The promise of vegetation for protecting beaches, dunes, and barrier islands from erosion. Front Ecol Environ 13:203-210

Frosini S, Lardicci C, Balestri E (2012) Global change and response of coastal dune plants to the combined effects of increased sand accretion (burial) and nutrient availability. PLoS ONE 7:e47561. doi:10.1371/journal.pone.0047561

Gonzalez P, Neilson RP, Lenihan JM, Drapek RJ (2010) Global patterns in the vulnerability of ecosystems to vegetation shifts due to climate change. Glob Ecol Biogeogr 19:755-768

Hacker SD, Zarnetske P, Seabloom E, Ruggiero P, Mull J, Gerrity S, Jones C (2012) Subtle differences in two nonnative congeneric beach grasses significantly affect their colonization, spread, and impact. Oikos 121:138-148

Hayden BP, Hayden NR (2003) Decadal and century long storminess changes at long-term ecological research sites. In: Greenwood D, Goodin GD, Smith RC (eds) Climate variability and ecosystem variability and response at longterm ecological research sites. Oxford University Press, New York, pp 262-285

He Q, Bertness MD (2014) Extreme stresses, niches, and positive species interactions along stress gradients. Ecology 95:1437-1443

Hoagland DR, Arnon DI (1950) The water-culture method for growing plants without soil. Circular, vol 347. The College of Agriculture, University of California, Berkley

Hodel RG, Gonzales E (2013) Phylogeography of sea oats (Uniola paniculata), a dune-building coastal grass in southeastern North America. J Hered 104:656-665

Jackson DA (1993) Stopping rules in principal components analysis: a comparison of heuristical and statistical approaches. Ecology 74:2204-2214

Lonard RI, Judd FW, Stalter R (2011) Biological flora of coastal dunes and wetlands: Uniola paniculata L. J Coastal Res 27:984-993

Masselink G, Heteren SV (2014) Response of wave-dominated and mixed-energy barriers to storms. Mar Geol 352: 321-347

Masterson JP, Fienen MN, Thieler ER, Gesch DB, Gutierrez BT, Plant NG (2014) Effects of sea-level rise on barrier island groundwater system dynamics-ecohydrological implications. Ecohydrology 7:1064-1071

Maun MA (1984) Colonizing ability of Ammophila breviligulata through vegetative regeneration. J Ecol 72:565-574

Maun MA, Lapierre J (1984) The effects of burial by sand on Ammophila breviligulata. J Ecol 72:827-839 
Miller TE (2015) Effects of disturbance on vegetation by sand accretion and erosion across coastal dune habitats on a barrier island. Ann Biol Plants 7:plv003. doi:10.1093/ aobpla/plv003

Miller DL, Yager L, Thetford M, Schneider M (2003) Potential use of Uniola paniculata rhizome fragments for dune restoration. Restor Ecol 11:359-369

Mousavi ME, Irish JL, Frey AE, Olivera F, Edge BL (2011) Global warming and hurricanes: the potential impact of hurricane intensification and sea level rise on coastal flooding. Clim Change 104:575-597

Parmesan C, Hanley ME (2015) Plants and climate change: complexities and surprises. Ann Bot 116:849-864

Roelvink D, Reniers A, van Dongeren A, de Vries JVT, McCall R, Lescinski J (2009) Modelling storm impacts on beaches, dunes and barrier islands. Coast Eng 56:1133-1152

Seabloom EW, Ruggiero P, Hacker SD, Mull J, Zarnetske P (2013) Invasive grasses, climate change, and exposure to storm-wave overtopping in coastal dune ecosystems. Glob Change Biol 19:824-832

Stallins JA (2002) Dune plant species diversity and function in two barrier island biogeomorphic systems. Plant Ecol 165:183-196

Stallins JA (2005) Stability domains in barrier island dune systems. Ecol Complex 2:410-430

Stallins JA, Parker AJ (2003) The influence of complex systems interactions on barrier island dune vegetation pattern and process. Ann Assoc Am Geogr 93:13-29

Taylor SH, Hulme P, Rees M, Ripley BS, Woodward FI, Osborne CP (2010) Ecophysiological traits in $\mathrm{C}_{3}$ and $\mathrm{C}_{4}$ grasses: a phylogenetically controlled screening experiment. New Phytologist 185:780-791

Thompson JA, Zinnert JC, Young DR (2017) Immediate effects of microclimate modification enhances native shrub encroachment. Ecosphere 8(2):e01687. doi:10.1002/ecs2. 1687

Uzoma KC, Inoua M, Andry H, Zahoor A, Nishihara E (2011) Influence of biochar application on sandy soil hydraulic properties and nutrient retention. J Food Agric Environ 9:1137-1143

van Heteren S (2014) Barrier systems. In: Masselink G, Geherls $\mathrm{R}$ (eds) Coastal environments and global change. Wiley, Hoboken, pp 194-226
Wagner RH (1964) The ecology of Uniola paniculata L. in the dune-strand habitat of North Carolina. Ecol Monogr 34:79-96

Walther GR, Post E, Convey P, Menzel A, Parmesan C, Beebee TJC, Fromentin JM, Hoegh-Guldberg O, Bairlein F (2002) Ecological responses to recent climate change. Nature 416:389-395

Wang D, Fan J, Heckathorn SA (2014) Acclimation of photosynthetic tolerance to acute heat stress at elevated $\mathrm{CO} 2$ and N. Plant Sci 266:162-171

Way DA, Katul GG, Manzoni S, Vico G (2014) Increasing water use efficiency along the C-3 to C-4 evolutionary pathway: a stomatal optimization perspective. J Exp Bot 65:3683-3693

Williams SJ (2013) Sea-level rise implications for coastal regions. 63:184-196. J Coast Res 63:184-196

Williams AC, McCarthy BC (2001) A new index of interspecific competition for replacement and additive designs. Ecol Res 16:29-40

Wolner CWV, Moore LJ, Young DR, Brantley ST (2013) Ecomorphodynamic feedbacks and barrier island response to disturbance: insights from the Virginia barrier islands, mid-Atlantic bight, USA. Geomorophology 199:115-128

Yaun T, Maun MA, Hopkins WG (1993) Effects of sand accretion on photosynthesis, leaf-water potential and morphology of two dune grasses. Funct Ecol 7:676-682

Ye XH, Yu FH, Dong M (2006) A trade-off between guerrilla and phalanx growth forms in Leymus secalinus under different nutrient supplies. Ann Bot 98:187-191

Zarnetske PL, Hacker SD, Seabloom EW, Ruggiero P, Killian JR, Maddux TB, Cox D (2012) Biophysical feedback mediates effects of invasive grasses on coastal dune shape. Ecology 93:1439-1450

Zarnetske PL, Gouhier TC, Hacker SD, Seabloom EW, Bokil VA (2013) Indirect effects and facilitation among native and non-native species promote invasion success along an environmental stress gradient. J Ecol 101:905-915

Zinnert JC, Shiflett SA, Vick JK, Young DR (2011) Woody vegetative cover dynamics in response to recent climate change on an Atlantic coast barrier island: a remote sensing approach. Geocarto Intl 26:595-612

Zinnert JC, Shiflett SA, Via S, Bissett S, Dows B, Manley P, Young DR (2016) Spatial-temporal dynamics in barrier island upland vegetation: the overlooked coastal landscape. Ecosystems. doi:10.1007/s10021-016-9961-6 